15 Keywords: Situated cognition; Cartesianism; distributed cognition; cognitive science; cognitive closure; Hayek's paradox; extended mind; enactivism; social epistemology

The title of this introduction captures what I take Friedrich August von

21 Hayek's life-long project to have been and thus summarizes the motivation behind this volume. Of course, Hayek is different things to different people,

23 ranging from well-founded, though selective, characterizations to illfounded and tiresome caricatures. Perhaps this is the fate of all genuine

25 polymaths, easily amenable to being coopted in the service of some ideological stance or subject to the more subtle phenomenon of exclusion

27 through disciplinary protectionism. Hayek was well aware of this twofold danger. Hayek didn't view himself in the way the grandiose term

29 "polymath" usually suggests but rather as a man interested in all aspects of human endeavor, none of which can easily be hived off without at some

31 point skewing the study. Hayek himself wrote:

exclusive concentration on a specialty has a peculiarly baneful effect: it will not merely prevent us from being attractive company or good citizens but may impair our competence in our proper field. (Hayek, 1967, pp. 123, 127)

That F. A. Hayek, Noble Prize-winner and best-selling author, wore a

37 nametag at a psychology conference (see the photograph on p. v) perhaps expresses the feeling that never really left him - that he was still (and would

39 probably remain) an interloper in matters of the mind. And so to the impetus for this volume. 
1 This collection of papers presents a sustained critical engagement with all aspects of Hayek's philosophical psychology - I view it as a companion to

3 the recent volume in this series edited by Bill Butos (2010). It builds on the first work I came across, the "early adopters/expositors" of Hayek's

5 theoretical psychology, notably Edelman (1982), Gray (1984), HerrmannPillath (1992), Streit (1993), Tuerck (1995), Birner (1995), Fuster (1995/

7 1999), Smith (1997), and the more recent second wave, comprising the sustained efforts of Horwitz (2000), Steele (2002), Caldwell (2004a, 2004b),

9 Baum (2004), Loasby (2004), McQuade and Butos (2006), Feser (2006), and Butos and Koppl (2007). Last, but by no means least, Weimer and Palermo

$11(1974,1982)$ - but that's a story that I'll get to shortly and warrants special treatment from the man himself (see the next essay).

13 Given the groundswell of interest in Hayek's philosophical psychology, the time is ripe to harvest some results and come to some provisional

15 conclusions about the nature and significance of Hayek's contributions to the philosophy of mind. As will become evident, assessment of the ultimate

17 significance of Hayek's work in cognitive science is highly contested and falls, broadly speaking, into two camps. Some take the view that Hayek's

19 supposedly prescient philosophical psychology has been overly neglected; others, by contrast, are of the view that his contributions have been

21 overstated. In an earlier paper (Marsh, 2010a), I marked this fault-line with two sets of questions:

23

- Is Hayek's philosophy of mind anachronistic because he was writing long

25 before the relevant options (i.e., the connectionist vs. the computational model) had been adequately defined? and/or

27 - Have Hayek's defenders been too charitable since he does not offer anything precise enough to fit any of the current models?

29

Or,

- Does his connectionist theory of mind entail the connectionist model of 33 society? or

- Does Hayek's connectionist model of society presuppose the connec-

35 tionist theory of mind?

37 In what follows I briefly (a) outline the appeal of Hayek's philosophical psychology to my work and (b) also acknowledge the generous support I've

39 received from Hayek scholars along the way. ${ }^{1}$ 


\section{HAYEK'S PARADOX, SITUATED AND} DISTRIBUTED COGNITION

Hayek's social epistemology is inextricably linked to his philosophical psychology. Indeed, the canonical and inextricably related Hayekian themes of complexity, distributed cognition, and spontaneous order, not to mention his famous critique of rationalism, all turn upon his theory of mind. Hayek's core presupposition - that mind is subject to terminal cognitive and epistemological constraint - crucially informs his social epistemology, philosophy of social science and social theory. To ameliorate this cognitive blind spot Hayek offers up his seminal insight - the ostensibly paradoxical notion that knowledge can become less incomplete only if it becomes more dispersed.

13 Cognitive closure (not a term ever used by Hayek) ${ }^{2}$ offers opportunity but also serves as a warning against epistemic immodesty. Opportunity

15 (or freedom) comes from the fact that knowledge is distributed; that is, knowledge that can be exploited is salient and meaningful to a given agent or group of agents with cognitive limitations. ${ }^{3}$ The ability to exploit what Clark so elegantly calls the "spreading of epistemic credit" (Clark, 1997, p. 69) is an adaptive consequence of mind being constitutionally constrained. As Hayek himself puts it: "All institutions of freedom are adaptations to this fundamental fact of ignorance ..." (Hayek, 1960/1978, p. 30, my emphasis). Here Hayek makes the distinctive link between mind and freedom. The always lurking temptation, the supposition that not only is there is such a thing as complete knowledge, but that it can be obtained, "frozen" and therefore grasped, is a pernicious fiction that the rationalist, some super mind, or plain old utopian is seduced by - a delusionary impulse that will surely corrode freedom.

27 To tamper with a given spontaneous order (essentially a coordination and communications system) is to compromise its epistemic veracity and efficiency: spontaneous orders are ipso facto cognitive orders. ${ }^{4}$

Although an arbitrary watershed, I take "recent" analytical philosophy of

31 mind to have begun with Ryle (1949). Hayek was of course au fait with Ryle's critique of Cartesian dualism but took as his project the discrediting 33 of Cartesian "individualism," the methodological supposition that cognition can be studied independently of any consideration of the body and the physical and ambient social environment, a position that is characteristic of orthodox philosophy of mind right up to the present. The epistemological flipside is the idea that knowledge relies solely upon, or is fashioned by, the operations of the cognizer's mental states without any appeal to external considerations. The sociological tradition, on the other hand, gives 
1 prioricity to the ubiquity of social considerations without any consideration to the mechanics of the individual mind.

3 The rise of non-Cartesian or "situated" cognitive science has understood that mind and sociality - Janus-like - cannot be pried apart. The situated

5 stance subscribes to the proposition that mind can only coherently exist at the nexus of the embodied, the social, and the artifactual. Whereas the

7 Cartesian cognizer is a fully decontextualized entity, for Hayek it would seem to be an essential fact about human cognition that it always operates

9 within a context of activity.

For Hayek, cognition is always perspectival and sociality is always 11 adjectival upon intrinsic cognitive architecture, and thus agents are necessarily subject to epistemic constraint. Selves (or minds if you will)

13 are only possible when embedded in a matrix of practices and traditions (habitus, skills, mores, "forms of life") in historically specific societies or

15 civilizations. This is the essence of Hayek's social externalism (theory of spontaneous orders) that finds confluence with the situated cognition

17 movement in general and the "enactivist" and "extended mind" strands in particular. Given the intrinsic dynamicism Hayek insists must be a part of

19 theorizing sociality, it seems to me that the enactivist theory of mind best articulates this requirement. Consider this (very Hayekian) excerpt from the

21 doyen of enactive theorists:

this power of culture and language to shape human subjectivity and experience belongs not simply to the genetic constitution of the individual, but to the generative constitution of the intersubjective community. Individual subjectivity is from the outset intersubjectivity, as a result of the communally handed down norms, conventions, artefacts, and cultural traditions in which the individual is always already embedded. Thus the internalization of joint attention into symbolic representations is not simply an ontogenetic phenomenon, but a historical and cultural one. (Thompson, 2007, p. 409)

29 The enactivist stance is a naturalistic non-reductive view of mind as embodied and embedded, giving due emphasis to biological autonomy and

31 lived subjectivity. These virtues are consonant with Hayek's emphasis on skillful know-how, a know-how that emerges from recurrent sensory-motor

33 coupling and looping between the organism and the artifactual environment (cf. Marsh, 2010a, 2010b). Consider also the work by another major theorist

35 of enactivism, Alva Noë. Noë emphasizes the usual hallmarks of situated theorists - dynamicism and contextualism - but also adds that we are

37 creatures of habit that, like tradition, is usually seen in pejorative terms and sidelined as irrational (2009).

39 Another strand or species of "situated" thinking that finds confluence in Hayek is the extended mind literature. It is interesting to note that Andy 
1 Clark and David Chalmers (1998), two of the most influential theorists in current philosophy of mind, and whose "extended mind/active externalism

3 thesis" became a major driver to the "situated cognition" movement, took some inspiration from Herbert Simon. Simon writes:

5

Human beings, viewed as behaving systems, are quite simple. The apparent complexity of our behavior over time is largely a reflection of the complexity of the environment in which we find ourselves ... [I] would like to view this information-packed memory less as part of the organism than as part of the environment to which it adapts.... (Simon, 1996, p. 53 , cf.8, 62, 99, 110)

What is really remarkable about this is that $\operatorname{Simon}^{5}$ in turn credits and endorses Hayek for this view:

No-one has characterized market mechanisms better than Friedrich von Hayek ... [His] defense did not rest primarily upon the supposed optimum attained by them but rather upon the limits of the inner environment - the computational limits of human beings. (Simon, 1996, p. 34)

What Simon has grasped are the two key presuppositions - cognitive closure and Hayek's spontaneous order externalism - that inform Hayek's philosophy of mind and its relationship to sociality. ${ }^{6}$

One prominent social epistemologist has explicitly referenced Hayek, making the connection between the Hungarian tradition of network theory, Marshall McLuhan's Toronto Circle and the Austrian tradition, all in some sense concerned with the mediated/extended mind (Nyíri, 2008; cf. Hardwick \& Marsh, forthcoming). Nyíri rightly notes that Hayek is primarily concerned with the communicative aspect of knowledge and has little or nothing to say about the artifacts brought to market, themselves vehicles of knowledge. This said, Hayek had a general appreciation of the cybernetic impact of sociality and so could easily accommodate the devices such as iPhones that Clark and Chalmers talk about (Chalmers, 2008). Furthermore, Hayek must surely acknowledge that artifactual devices such as iPhones are part and parcel of a "meta extended cognitive" system.

Social epistemology has traditionally been Marxist-inspired and, not surprisingly, has been the preserve of the sociological tradition. Only recently has social epistemology gained a semblance of respectability in analytical (individualistic) epistemology circles. If social epistemology has the formation, acquisition, mediation, transmission, and dissemination of knowledge in complex communities of knowers as its subject matter, then Hayek is a social epistemologist par excellence, and the preeminent (nonMarxist) one at that, making him ripe for adoption by the analytical community. Hayek's work has much to say to about "bread and butter" 
1 topics in social epistemology, namely collective intentionality, judgment aggregation, expertise, patterns, institutions and networks of communica-

3 tion and, of course, that for which he is most famous, distributed cognition and knowledge.

5 If I may be permitted to proffer a prediction, given Hayek's understanding of the intimate link between social epistemology and mind, he will

7 become the touchstone theorist in this field. Already some social epistemologists are looking at the extended mind literature (Goldberg,

9 2007; Prichard, 2010) and one philosopher of mind grasps the social implications of the extended mind thesis (Wilson, 2004).

15 As I mentioned earlier, Hayek is many different things to many different people. The Hayek I knew was the representative methodological

17 individualist from a philosophy of social science course, a philosophical jurisprudence theorist from a political philosophy course, and, in the

19 popular imagination, the "poster boy" for libertarianism.

Professionally speaking, Hayek was somewhat neurotic about being

21 accepted as a scientist generally and a cognitive scientist in particular. $\mathrm{He}$ writes: "After The Road to Serfdom, I felt that I had so discredited myself

23 professionally, I didn't want to give offence again. I wanted to be accepted in the scientific community" (Hayek, 1994, p. 152).

25 So how did I come to discover the philosophical psychology Hayek? I had the good fortune to come across Roger Koppl at the EPISTEME conference

27 on social epistemology held at Rutgers in 2007. While I was tinkering on a paper that had themes of complexity, distributed cognition, spontaneous

29 order and rationalism as its subject matter (Marsh \& Onof, 2008), Roger leaned over and asked what I was working on. I mumbled "complexity" and

31 accidentally dropped in "Hayek." I was expecting to be admonished - this was, after all, a venue for analytical epistemologists and, as I've said, Hayek

33 was not really known in this context. Gingerly, I agreed to let Roger look the paper over and very quickly he suggested that I get in touch with Bill

35 Butos, who was already editing a companion volume to this one (Butos, 2010). Bill's kind accommodation as a late entry forced me to fully immerse

37 myself in the Hayek corpus, re-reading the popular "way in" to Hayek, namely The Road to Serfdom as well as, at the other extreme, reading for the

39 first time the dense The Sensory Order (Hayek, 1952/1976), and everything in between. The fruits of this study resulted in the paper (Marsh, 2010a) in 
1 which I assessed Hayek's contribution to cognitive science generally, to the non-Cartesian wing of cognitive science in particular, and the relationship,

3 on Hayek's account, between mind and sociality.

In the course of writing the aforementioned paper one name kept 5 recurring - Walter Weimer. It was clear from his co-edited work (Weimer \& Palermo, 1982) that there was a highly distinctive mind at work, and more

7 so since here was a professor of psychology in a major university engaging with Hayek - in 1977! I'd imagine that this would be professional suicide.

9 Who would have had the gall to invite an interloper such as Hayek to "The Second Penn State Conference on Cognition and the Symbolic Processes," a

11 conference convened by Weimer and his recently deceased colleague, David Palermo. $^{7}$ I was determined to track Weimer down and get the inside 13 scoop. $^{8}$

It took someone such as Weimer, himself "a marginal" character, to get

15 Hayek "another marginal" character to the conference as a full and active participant, 25 years after The Sensory Order was first published.

17 Furthermore, it takes a brave man to accept such an invitation - after all, not only was Hayek close to eighty years old but he also wasn't exactly in

19 philosophical psychology mode - he was probably preparing his last two "officially sanctioned" works (Hayek, 1978, 1979). ${ }^{9}$ And anyway, why

21 would Hayek, still very much basking in the fame of Nobel glory, be tempted to revisit the book that in Hume's immortal words "fell stillborn

23 from the press"? The conference with a panel devoted to The Sensory Order was billed as follows:

The purpose of this conference, as with the previous one held in 1972, is to examine in detail selected topics in cognitive psychology in the hope that their in-depth discussion will both summarize our current knowledge in the area and also tell us where to go in future theorizing and research. Recognizing the current revolution within cognitive psychology, the main concern is to summarize the lessons learned from past attempts to construct a psychology of the higher mental processes and, more importantly, to crystallize specific directives and research proposals for where cognitive psychology ought to go in the future. ${ }^{10}$

33 Thirty-five years on from this conference (and 60 years since its publication), The Sensory Order is still being discussed. Not many

35 philosophers of mind can make that claim for their work, let alone an interloper such as Hayek. Readers seeking simplistic hagiography will be

37 disappointed: even the more sanguine of writers in this volume enter into critical engagement. The upshot is that Hayek is worth taking on - the

39 diverse group of neuroscientists, economists, philosophers, and psychologists participating in this project certainly think so. 
The chapters comprising this volume suggest a natural threefold clustering: neuroscience, philosophy of mind, and mind and sociality - overlapping interest

3 is, of course, not precluded. In the first section, two practicing neuroscientists, Fuster and Başar, see the fertility of Hayek's "explanation of the principle"

5 informing their empirical work. The philosophy of mind section kicks off with three writers well-known for their work in the field - Rust, Ross, and Feser. Rust

7 offers a critical explication of The Sensory Order in light of current connectionist thinking. Ross examines the link between Hayek's connectionist theory of mental

9 architecture and descriptive and normative individualism. Feser sets out Hayek's causal theory of the mind and criticisms thereof in light of contemporary

11 philosophy of mind. Wible, an economist with a dual interest in psychology, looks at Hayek and Peirce's relational interpretations of sensation and cognition.

13 Jan Willem Lindemans brings to his broad methodological and epistemological interests to bear on the vexed question of to what degree Hayek was a Kantian.

15 Becchio rounds off this section with a brief examination of the Mach-Kant and Hayek-Mach relationship. The mind and sociality section opens with Zúñiga y

17 Postigo's explicit linkage of spontaneous order, mind and collective intentionality. Chelini, in similar vein, discusses the hot topic of mirror neurons. Cheung

19 makes the case for a direct link between Hayek's philosophical psychology and the liberalism for which Hayek is best known. Aimar brings his dual interest in

21 economics and the psychology of decision making to bear on entrepreneurial behavior and the Austrian tradition. Closing out the volume, Camplin's panoptic

23 chapter bridges Hayek's theory of the mind to his work on spontaneous orders.

\section{UNCITED REFERENCES}

Hayek (1952/1979).

\section{NOTES}

1. The historical background to Hayek's philosophy of mind has already been well covered. In any event, much of it is revisited across the essays in this volume and all roads lead to a handful of names.

2. The term was coined by Colin McGinn (1989).

3. It is a mark of the human condition that humankind is terminally subject to these limitations.

4. This is not an argument for the laissez-faire state. For Hayek, whether the state 39 should or should not "interfere," poses a false dichotomy: every state must act. For Hayek, the healthy functioning of a market presupposes institutions that cannot be 
1 provided by the market. Freedom and liberty on Hayek's account (indeed the very concept of liberalism) exists at the nexus of a manifold of spontaneous forces with no single epistemic system dominating. This view is in stark contrast with some selfavowed Hayekians and critics alike who attribute to Hayek the view that the market is the root of social order. See Hardwick and Marsh (forthcoming); Marsh (2012).

5 5. Simon, a near contemporary of Hayek, was the only polymath who approximated Hayek - political scientist, sociologist, psychologist, computer scientist, economist - and, of course, winner of the Nobel Prize for economics (1978).

6. Although the reception to The Sensory Order was lukewarm, much of Hayek's later work is replete with abridged references to cognitive closure.

9 7. For more on Palermo see: http://www.legacy.com/obituaries/centredaily/ obituary.aspx? $\mathrm{n}=$ david-stuart-palermo\&pid $=149679996$

11 8. Through my interest in Weimer I was able to enter into a dialogue with some of his students, namely Bill Butos (Trinity), Jim Wible (New Hampshire), Harry Heft (Denison), Denny Proffitt (Virginia), and John Johnson (Penn State). The dedication 13 of this book is to my friend Rob Haskell who died before he could tell me more about Weimer. Rob was also slated as a contributor.

15 9. See Alan Ebenstein on this controversy: http://web.archive.org/web/ 20080622201757/http://libertyunbound.com/archive/2005_03/ebenstein-deceit.html\#3

10. This is from the original conference flyer that was supplied to me by Jim Wible. Also in attendance were none other than J. J. Gibson who, I'm told, snubbed Hayek, despite apparently warmly receiving The Sensory Order, and Eleanor Rosch,

19 who later became a major proponent of enactivism, along with Francesco Varela and Evan Thompson (Varela, Thompson \& Rosch, 1991).

\section{ACKNOWLEDGMENTS}

25 As is my usual practice, I want to register the diligent and all too often under appreciated work provided by referees: Gustav Bernroider (Salzburg), Jack

27 Birner (Trento), Pete Boettke (George Mason), Scott Boykin (Georgia Gwinnett College), Steve Bressler (Florida Atlantic), Bruce Caldwell

29 (Duke), Rafe Champion, Gus diZerega (Studies in Emergent Order), Giuseppina D'Oro (Keele), Peter Earl (Queensland), Roger Franz (San

31 Diego State), Andrew Gamble (Cambridge), Jerry Gaus (Arizona), Lauren Hall (Rochester Institute of Technology), Eugene Heath (SUNY-New

33 Paltz), Carsten Herrmann-Pillath (Frankfurt School of Finance and Management), Camilla Josephson (Linköpings), Byron Kaldis (Hellenic

35 Open University), Elias Khalil (Monash), Chandaran Kukathas (LSE), Bertram Malle (Brown), Thomas McQuade, Maurizio Mistri (Padova),

37 Anthony O'Hear (Buckingham), Chris Onof (Imperial), Paul Pojman (Towson), Aeon Skoble (Bridgewater), Barry Smith (Buffalo), Subrena

39 Smith (Cornell), Gerry Steele (Lancaster), David Tuerck (Suffolk), Stephen Turner (South Florida), Geoff Thomas (Birkbeck), Viktor Vanberg 
1 (Freiburg), Cornelis de Waal (Indiana-Purdue), Nikolai Wenzel (Hillsdale), and Gabriel Zanotti (Austral University). Two who were burdened with

3 double-duty are Ed Feser and Gloria Zúñiga y Postigo. Thanks also to Josiah Lee Auspitz, Eric Mack (Tulane) and Terry Sejnowski (Salk

5 Institute) for some insightful referrals. I am most appreciative to Roger Koppl for affording me the opportunity to do this volume; Steve Horwitz 7 for keeping me in the "Hayek loop" primarily through the Society for the Development of Austrian Economics; and Mario Rizzo for so kindly letting

9 me be a part of the weekly Colloquium on Market Institutions and Economic Processes at NYU where I was fortunate to meet several others

11 that shared my interests. Last, but by no means least, thanks to Shannon Selin, Chris Onof, Geoff Thomas, David Livingstone Smith, Gene Callahan

13 (and his family), Dave Hardwick, Ray Russ, and Merredith Hung for their practical support dispensed in different ways.

\section{REFERENCES}

Baum, E. (2004). The language of thought. Cambridge: MIT Press.

21 Birner, J. (1995). The surprising place of cognitive psychology in the work of F. A. Hayek. Research Memoranda. Retrieved from http://edocs.ub.unimaas.nl/loader/file.asp?id1/4417

Butos, W. N. (2010). The unexpected fertility of Hayek's cognitive theory: An introduction to the social science of Hayek's "The Sensory Order". In: W. Butos (Ed.), The social science of Hayek's "the sensory order." Advances in Austrian Economics (Vol. 13, pp. 1-20). Bingley: Emerald.

Butos, W. N., \& Koppl, R. G. (2007). Does the sensory order have a useful economic future? Cognition and Economics. Advances in Austrian Economics, 9, 19-50.

Caldwell, B. (2004a). Some reflections on F.A. Hayek's the sensory order. Journal of Bioeconomics, 6, 239-254.

Caldwell, B. (2004b). Hayek's challenge: An intellectual biography of F.A. Hayek. Chicago, IL: University of Chicago Press.

Chalmers, D. (2008). Forward to any Clark's supersizing the mind: Embodiment, action, and cognitive extension. Oxford: Oxford University Press.

Clark, A. (1997). Being there: Putting brain, body, and world together again. Cambridge, MA: MIT Press.

Clark, A., \& Chalmers, D. (1998). The extended mind. Analysis, 58(1), 7-19.

35 Edelman, G. M. (1982). Through a computer darkly: Group selection and higher brain function. Bulletin of the American Academy of Arts and Sciences, 36(1), 20-49.

Feser, E. (2006). Hayek the cognitive scientist and philosopher of mind. In: E. Feser (Ed.), The Cambridge companion to Hayek. Cambridge: Cambridge University Press.

Fuster, J. M. (1999). Memory in the cerebral cortex: An empirical approach to neural networks in the human and nonhuman primate. Cambridge: MIT Press. 
1 Goldberg, S. (2007). Anti-individualism: Mind and language, knowledge and justification. Cambridge: Cambridge University Press.

Gray, J. N. (1984). Hayek on liberty. Oxford: Basil Blackwell.

Hardwick, D. F., \& Marsh, L. (forthcoming). Clash of the titans: When the market and science collide. Advances in Austrian Economics. Bingley: Emerald.

5 Hayek, F. A. (1976). The sensory order: An inquiry into the foundations of theoretical psychology. Chicago, IL: Chicago University Press.

7 Hayek, F. A. (1979). The counter-revolution of science: Studies on the abuse of reason. Indianapolis, IN: Liberty Fund Press.

Hayek, F. A. (1978). The constitution of liberty. Chicago, IL: University of Chicago Press.

Hayek, F. A. (1967). Studies on philosophy, politics and economics. Chicago, IL: University of Chicago Press.

11 Hayek, F. A. (1978). New studies in philosophy, politics, economics and the history of ideas. Chicago, IL: University of Chicago Press.

Hayek, F. A. (1979). Law, legislation and liberty. Vol. 3: The political order of a free people. Chicago, IL: University of Chicago Press.

Hayek, F. A. (1994/1998). Hayek on Hayek: An autobiographical dialogue. In: S. Kresge \& L. Wenar (Eds.), Indianapolis, IN: Liberty Fund Press.

Herrmann-Pillath, C. (1992). The Brain, its sensory order, and the evolutionary concept of mind: On Hayek's contribution to evolutionary epistemology. Journal of Social and Evolutionary Systems, 15(2), 145-186.

Horwitz, S. (2000). From the sensory order to the liberal order: Hayek's non-rationalist liberalism. Review of Austrian Economics, 13, 23-40.

Loasby, B. J. (2004). Hayek's theory of the mind. Advances in Austrian Economics, 7, 101-134.

21 Marsh, L. (2010a). Hayek: Cognitive scientist avant le lettre. In: W. Butos (Ed.), The social science of Hayek's "The sensory order." Advances in Austrian Economics (Vol. 13, pp. 115-155). Bingley: Emerald.

Marsh, L. (2010b). Ryle and Oakeshott on the "knowing-how/knowing-that" distinction. In: C. Abel (Ed.), The meanings of Michael Oakeshott's conservatism. Exeter: Imprint Academic.

25 Marsh, L. (2012). Oakeshott and Hayek: Situating the mind. In: P. Franco \& L. Marsh (Eds.), A companion to Michael Oakeshott. University Park: Penn State University Press.

27 Marsh, L., \& Onof, C. (2008). Stigmergic epistemology, stigmergic cognition. Cognitive Systems Research, 136-149.

29 McGinn, C. (1989). The problem of consciousness. Oxford: Blackwell.

McQuade, T. J., \& Butos, W. (2006). The sensory order and other adaptive classifying systems. Journal of Bioeconomics, 7, 335-358.

31 Noë, A. (2009). Out of our heads: Why you are not your brain, and other lessons from the biology of consciousness. New York, NY: Hill and Wang.

33 Nyíri, K. (2008). The networked mind. Studies in Eastern European Thought, 60, 149-158.

Prichard, D. (2010). Cognitive ability and the extended cognition thesis. Synthese, 175. (Supplement 1), 133-151.

35 Ryle, G. (1949). The concept of mind. London: Hutchinson.

Simon, H. A. (1996). The sciences of the artificial (3rd ed.). Cambridge, MA: MIT Press.

37 Smith, B. (1997). The connectionist mind: A study of Hayekian psychology. In: S. F. Frowen (Ed.), Hayek: Economist and social philosopher: A critical retrospect (pp. 9-29). London: Macmillan.

Steele, G. R. (2002). Hayek's sensory order. Theory \& Psychology, 12(3), 125-147. 
xxiv “SOCIALIZING” THE MIND AND “COGNITIVIZING” SOCIALITY

1 Streit, M. E. (1993). Cognition, competition and catallaxy: In memory of Friedrich August von Hayek. Constitutional Political Economy, 4(2), 223-262.

3 Thompson, E. (2007). Mind in life: Biology, phenomenology, and the sciences of the mind. Cambridge, MA: Harvard University Press.

5

Tuerck, D. G. (1995). Economics as mechanism: The mind as machine in Hayek's sensory order. Constitutional Political Economy, 6, 281-292.

Varela, F., Thompson, E., \& Rosch, E. (1991). The embodied mind: Cognitive science and human experience. Cambridge, MA: MIT Press.

Weimer, W. B., \& Palermo, D. S. (Eds.). (1974). Cognition and the symbolic processes (Vol. 1). Hillsdale: Lawrence Erlbaum Associates.

Weimer, W. B., \& Palermo, D. S. (Eds.). (1982). Cognition and the symbolic processes. NJ: Lawrence Erlbaum Associates.

11 Wilson, R. A. (2004). Boundaries of the mind: The individual in the fragile sciences: Cognition. Cambridge: Cambridge University Press.

13 


\section{AUTHOR QUERY FORM}

\begin{tabular}{|l|l|l|}
\hline Emerald & $\begin{array}{l}\text { Book: AAEC-V015- } \\
3610403\end{array}$ & $\begin{array}{c}\text { Please e-mail or fax your responses } \\
\text { and any corrections to: }\end{array}$ \\
Chapter: 20 & $\begin{array}{l}\text { E-mail: } \\
\text { Fax: }\end{array}$ \\
\hline
\end{tabular}

Dear Author,

During the preparation of your manuscript for typesetting, some questions may have arisen. These are listed below. Please check your typeset proof carefully and mark any corrections in the margin of the proof or compile them as a separate list.

\section{Disk use}

Sometimes we are unable to process the electronic file of your article and/or artwork. If this is the case, we have proceeded by:

\section{Scanning (parts of) your article $\square$ Rekeying (parts of) your article}

Scanning the artwork

\section{Bibliography}

If discrepancies were noted between the literature list and the text references, the following may apply:

The references listed below were noted in the text but appear to be missing from your literature list. Please complete the list or remove the references from the text.

UNCITED REFERENCES: This section comprises references that occur in the reference list but not in the body of the text. Please position each reference in the text or delete it. Any reference not dealt with will be retained in this section.

Queries and/or remarks

\begin{tabular}{|l|l|l|}
\hline $\begin{array}{l}\text { Location in } \\
\text { Article }\end{array}$ & \multicolumn{1}{|c|}{ Query / remark } & Response \\
\hline AU:1 & $\begin{array}{l}\text { Please provide other } \\
\text { subheadings (if possible) in the } \\
\text { Abstract. }\end{array}$ & \\
\hline AU:2 & $\begin{array}{l}\text { As per Emerald style, up to six } \\
\text { keywords are allowed. Please } \\
\text { choose the six keywords that } \\
\text { should be retained. }\end{array}$ & \\
\hline AU:3 & $\begin{array}{l}\text { The reference citation 'Weimer } \\
(1974,1982) \text { ' has been replaced } \\
\text { with 'Weimer and Palermo (1974, } \\
1982) \text { ' as per the reference list. } \\
\text { Please check for correctness. }\end{array}$ & \\
\hline
\end{tabular}




\begin{tabular}{|l|l|l|} 
AU:4 & $\begin{array}{l}\text { Please provide the text citation } \\
\text { for reference 'Hayek (1952/ } \\
\text { 1979)'. If no citation is available, } \\
\text { the reference should be deleted } \\
\text { from the list. }\end{array}$ & \\
\hline AU:5 & $\begin{array}{l}\text { Please validate the following } \\
\text { URL: http:// } \\
\text { edocs.ub.unimaas.nl/loader/ } \\
\text { file.asp?id } \frac{1}{4} 417 .\end{array}$ & \\
\hline AU:6 & $\begin{array}{l}\text { Please update ref. Hardwick \& } \\
\text { Marsh (forthcoming) with year. }\end{array}$ & \\
\hline AU:7 & $\begin{array}{l}\text { Please provide the city of the } \\
\text { publisher in ref. Weimer \& } \\
\text { Palermo (1982). }\end{array}$ \\
\hline
\end{tabular}

